\title{
Keterkaitan Karakteristik Pergerakan di Kawasan Pinggiran Terhadap Kesediaan Menggunakan BRT di Kota Palembang
}

\author{
Dian Nur'afalia, Ketut Dewi Martha Erli Handayeni \\ Departemen Perencanaan Wilayah dan Kota, Fakultas Teknologi Sipil dan Perencanaan, Institut \\ Teknologi Sepuluh Nopember (ITS) \\ e-mail: erli.martha@gmail.com
}

\begin{abstract}
Abstrak-Kota Palembang merupakan salah satu kota berkembang dengan permasalahan transportasi yang cukup besar. Salah satu wilayah dengan permasalahan transportasi adalah Kecamatan Alang-Alang Lebar. Kecamatan Alang-Alang Lebar berdasarkan fisik dan lokasi diidentifikasi sebagai kawasan pinnggiran Kota Palembang. Permasalahan transportasi di wilayah pinggiran adalah peningkatan penggunaan kendaraan pribadi menuju pusat Kota Palembang. Dari permasalahan tersebut terdapat potensi penggunaan BRT dari wilayah pinggiran. Untuk itu, perlu diketahui keterkaitan antara potensi penggunaan BRT dengan karakteristik masyarakat yang menggunakan kendaraan pribadi. Penelitian ini menggunakan metode analisis Crosstab dengan melihat keterkaitan antara karakteristik pergerakan yaitu asal pergerakan, maksud pergerakan, jarak perjalanan dan moda yang digunakan dengan kesediaan masyarakat menggunakan BRT. penelitian menunjukan bahwa bahwa tidak ada keterkaitan antara asal pergerakan, maksud pergerakan dan moda yang digunakan dengan kesediaan masyarakat menggunakan BRT. Kesediaan menggunakan BRT memiliki keterkaitan yang signifikan dengan karakteristik lama perjalanan dari wilayah pinggiran menuju pusat kota.
\end{abstract}

Kata kunci- karakteristik pergerakan, Crosstab.

\section{PENDAHULUAN}

K OTA Palembang merupakan salah satu kota berkembang di Indonesia. Perkembangan yang terjadi terlihat pembangunan dan perkembangan jumlah penduduk. Seiring dengan perkembangan yang terjadi, terdapat permasalahan perkotaan yaitu transportasi. Permasalahan transportasi yaitu kemacetan merupakan sebuah permasalahan yang sering terjadi di kota berkembang [1]. Angkutan umum yang diharapkan mampu menjadi solusi bagi permasalahan transportasi belum dapat menjalankan perannya dengan optimal. Padahal, angkutan umum memiliki peran dalam melayani mobilitas masyarakat perkotaan untuk mengatasi permasalahan transportasi [1]. Pengembangan angkutan massal telah terjadi di Kota Palembang sejak tahun 2002. Selanjutnya, pada awal tahun 2010 telah dilakukan dikembangkan angkutan umum massal (BRT) dengan sebutan Bus Transmusi namun peningkatan penggunaan kendaraan pribadi terus meningkat.
Tujuan pengembangan BRT sebagai angkutan utama di Palembang belum optimal. Hal ini dapat dilihat pada studi yang telah dilakukan oleh Joni A (2013), bahwa 33\% pelaku transportasi menggunakan motor sebagai kendaraan utama dan $31 \%$ menggunakan angkutan kota [2]. Hal ini dikarenakan pergerakan lebih mudah dan cepat dengan kendaraan pribadi [2]. Dari permasalahan tersebut, potensi permintaan akan BRT di Palembang cukup tinggi. Diketahui sebanyak 29.652 dari 49.420 sampel pada Kecamatan Gandus, atau 64\% dari sampel penelitian merupakan potensi permintaan BRT [2]. Hal ini menjadi sebuah permasalahan ketika keinginan masyarakat untuk menggunakan BRT tinggi namun pada kenyataannya pengguna kendaraan pribadi di Kota Palembang masih tinggi.

Pengguna kendaraan pribadi yang cukup tinggi terjadi di pinggiran Kota Palembang. Hal ini dikarenakan pertumbuhan permukiman yang cukup tinggi di wilayah pinggiran Kota Palembang, menyebabkan angkutan umum belum dapat melayani keseluruhan wilayah. Wilayah pinggiran dengan penggunaan kendaraan pribadi yang tinggi yaitu Kecamatan Alang-Alang Lebar. Kecamatan Alang-Alang Lebar memiliki potensi pergerakan menuju pusat kota dan potensi perubahan moda transportasi dari moda pribadi ke BRT sebesar 41.040 pergerakan [3]. Untuk mengatasi permasalahan tesebut dibutuhkan pengembangan transportasi sehingga masyarakat dapat menjangkau angkutan umum. Namun, untuk mengembangkan sebuah konsep transportasi dibutuhkan identifikasi karakteristik pergerakan terlebih dahulu dan Keterkaitannya dengan tingkat kesediaan menggunakan BRT menuju pusat kota.

Identifikasi ini bertujuan untuk mengetahui karakter masyarakat yang mempengaruhi konsep transportasi yang akan dikembangkan di Kecamatan Alang-Alang Lebar. Dari karakteristik tersebut kemudian akan dilihat keterikatan antar variabel yang mempengaruhi kesediaan masyarakat menggunakan BRT.

\section{METODOLOGI PENELITIAN}

\section{A. Variabel Penelitian}

Penelitian kali ini merupakan jenis penelitian deskriptif dan eksperimental yang menghubungkan pengaruh variabel ke variabel lainnya. Variabel penelitian adalah faktor yang dapat 
diukur, baik ukuran yang bersifat kuantitatif maupun kualitatif. Penentuan variabel penelitian berdasarkan pada identifikasi karakteristik pelaku pergerakan hasil dari sintesa pustaka, sebagai berikut:

Tabel 1.

Variabel Penelitian

\begin{tabular}{|c|c|c|c|}
\hline No & Indikator & Variabel & Definisi Operasional \\
\hline \multirow[t]{4}{*}{1} & $\begin{array}{l}\text { Karakteristik } \\
\text { pergerakan }\end{array}$ & Asal perjalanan & $\begin{array}{l}\text { Lokasi rumah pengguna } \\
\text { kendaraan pribadi }\end{array}$ \\
\hline & & Maksud perjalanan & $\begin{array}{l}\text { Dinyatakan dengan } \\
\text { masud perjalanan yang } \\
\text { dilakukan oleh pelaku } \\
\text { pergerakan }\end{array}$ \\
\hline & & $\begin{array}{l}\text { Moda yang } \\
\text { digunakan }\end{array}$ & $\begin{array}{l}\text { Dinyatakan dengan moda } \\
\text { yang digunakan oleh } \\
\text { pelaku pergerakan }\end{array}$ \\
\hline & & Jarak perjalanan & $\begin{array}{l}\text { Dinyatakan dengan jarak } \\
\text { perjalanan pelaku } \\
\text { pergerakan menggunakan } \\
\text { kendaraan pribadi menuju } \\
\text { tujuan perjalanan dan } \\
\text { halte BRT terdekat. Jarak } \\
\text { tersebut juga akan } \\
\text { dipengaruhi oleh lintasan } \\
\text { atau rute pergerakan } \\
\text { masyarakat. }\end{array}$ \\
\hline
\end{tabular}

Kesediaan Keinginan masyarakat menggunakan BRT menggunakan BRT jika terdapat jaringan feeder
Dengan jumlah sampel terjangkau yaitu 17527 dengan nilai eror sebesar $8 \%$, maka jumlah sampel yang ditentukan adalah sebanyak:

$\mathrm{n}=17527 /\left(1+17527 .(0.08)^{2}\right)$

$\mathrm{n}=156$

Sehingga diketahui jumlah sampel pada penelitian adalah 156 KK di Kecamatan Alang-Alang Lebar dengan pembagian sampel untuk masing-masing kelurahan adalah sebagai berikut:

Tabel 2.

Persebaran Jumlah Sampel Berdaasarkan Kelurahan

\begin{tabular}{cccc}
\hline \hline No. & Nama Kelurahan & Jumlah KK & $\begin{array}{c}\text { Jumlah } \\
\text { Sampel }\end{array}$ \\
\hline 1. & Kelurahan Srijaya & 4459 & 40 \\
2. & Kelurahan Karya Baru & 4962 & 44 \\
3. & Kelurahan Talang Kelapa & 6875 & 61 \\
4. & Kelurahan Alang-Alang Lebar & 1231 & 11 \\
& Jumlah & 17527 & 156 \\
\hline \hline
\end{tabular}

Dari 156 sampel KK yang didapat, terdapat 239 pergerakan yang terjadi. 239 sampel tersebut kemudian dijadikan sebagai sampel pergerakan untuk diteliti karakteristik pergerakannya. Sampel diatas dianggap representatif dalam mewakili populasi pada penelitian ini. Metode pengambilan data dibedakan 2 yaitu pengambilan data sekunder dan pengambilan data primer. Pengambilan data primer akan dilakukan melalui observasi oleh peneliti dan penyebaran kuesioner. Data primer yang dibutuhkan adalah berupa data karakteristik pelaku pergerakan yaitu asal pergerakan, maksud pergerakan, lama pergerakan dan moda yang digunakan dalam melakukan pergerakan. Secara keseluruhan, data, metode pengambilan data dapat dilihat pada tabel berikut:

Tabel 1.

Metode Pengambilan Data Primer

\begin{tabular}{|c|c|c|}
\hline Data & Teknik & Sumber Data \\
\hline Jarak perjalanan dari & & Sampel pengguna \\
\hline asal ke tujuan & & kendaraan pribadi di \\
\hline $\begin{array}{c}\text { Asal pergerakan } \\
\text { pelaku pergerakan }\end{array}$ & & $\begin{array}{l}\text { Kecamatan Alang- } \\
\text { Alang Lebar. }\end{array}$ \\
\hline $\begin{array}{l}\text { Maksud perjalanan } \\
\text { pelaku pergerakan }\end{array}$ & & \\
\hline $\begin{array}{c}\text { Kendaraan yang } \\
\text { paling sering } \\
\text { digunakan }\end{array}$ & & \\
\hline
\end{tabular}

\section{Teknik Analisis}

Pergerakan terbentuk akibat adanya aktifitas yang dilakukan bukan di tempat tinggalnya. Artinya keterkaitan antar wilayah ruang sangatlah berperan dalam menciptakan perjalanan dan pola sebaran tata guna lahan sangat mempengaruhi pola perjalanan orang [1]. Dari pergerakan tersebut, masing-masing wilayah memiliki karakteristik yang berbeda dan menentukan pola pergerakan yang akan menentukan rencana pengembangan transportasi pada suatu wilayah sehingga dibutuhkan identifikasi karakteristik pergerakan. Identifikasi karakteristik pergerakan di Pinggiran Kota Palembang, yaitu di Kecamatan Alang-Alang Lebar, bertujuan untuk mengetahui
$\mathrm{n}=\mathrm{N} /\left(1+\mathrm{N} .(\mathrm{e})^{2}\right)$

Keterangan :

$\mathrm{n}=$ Jumlah Sampel

$\mathrm{N}=$ Jumlah Total Populasi

$\mathrm{e}=$ Batas Toleransi Error, yang umumnya digunakan $8 \%$ 
asal dan tujuan pergerakan pelaku perjalanan. Selain itu, identifikasi ini juga diperlukan untuk mengetahui sebab terjadinya pergerakan, waktu terjadinya pergerakan dan moda yang digunakan dalam pergerakan [1]. Untuk mengidentifikasi karakteristik pelaku pergerakan, metode yang digunakan adalah metode deskriptif kuantitatif. Metode deskriptif kuantitatif bertujuan untuk menjelaskan suatu fenomena yang terjadi menggunakan angka-angka, tabel, diagram atau kurva dengan jelas sehingga muncul penggambaran data yang diharapkan. Pada penelitian ini, metode analisis deskriptif kuantitatif akan menjelaskan terkait karakteristik pergerakan dari hasil kuesioner dan observasi menggunakan angka, diagram atau kurva sehingga tergambar dengan jelas karakteristik pergerakan yang dapat digunakan untuk sasaran selanjutnya.

Selanjutnya, dari karakteristik tersebut akan dicari keterkaitan antar karakteristik dengan kesediaan masingmasing sampel untuk menggunakan BRT. Metode Analisis yang digunakan dalam tujuan ini adalah menggunakan analisis Crosstab atau tabulasi silang dengan bantuan software SPSS 20. Adapun pengujian dalam analisis ini adalah: uji chi square, uji koefisien kontingensi, dan uji taraf signifikan. Ketiga pengujian tersebut digunakan untuk menguji masing-masing variabel untuk melihat pengaruhnya terhadap kesediaan masyarakat menggunakan BRT. Hipotesis yang digunakan dalam proses analisis ini di antaranya berupa:

Ho : Tidak ada hubungan antara karakteristik pergerakan masyarakat dengan kesediaan menggunakan BRT

Hi : Ada hubungan antara karakteristik pergerakan masyarakat dengan kesediaan menggunakan BRT. Nilai-nilai yang dihasilkan dalam proses analisis kemudian disimpulkan berdasarkan ketentuan dan dasar pengambilan keputusan yang ada sesuai dengan ketiga uji yang dilakukan.

\section{HASIL DAN DISKUSI}

\section{A. Idetifikasi Karakteristik Pergerakan Masyarakat}

Identifikasi karakteristik pergerakan di Kecamatan AlangAlang Lebar didasarkan pada variabel penelitian sebagai berikut:

1) Asal Pergerakan

Setelah dilakukan proses analisis hasil dari kuesioner terhadap sampel, didapat data asal pergerakan masyarakat. Berikut merupakan data asal pergerakan masyarakat:

Tabel 4.

Data Asal Pergerakan

\begin{tabular}{lcc}
\hline \hline \multicolumn{1}{c}{ Kelurahan } & Jumlah Pergerakan & Presentase (\%) \\
\hline Karya Baru & 100 & 41,8 \\
Talang Kelapa & 72 & 30,1 \\
AAL & 10 & 4 \\
Srijaya & 57 & 23,8 \\
Total & 239 & 100 \\
\hline \hline
\end{tabular}

Dari tabel diatas, dilihat bahwa dari 239 pergerakan sebesar $41,8 \%$ berasal dari Kelurahan Karya Baru. Hasil ini menunjukan bahwa permintaan akan angkutan umum paling besar berasal dari Kelurahan Karya Baru.

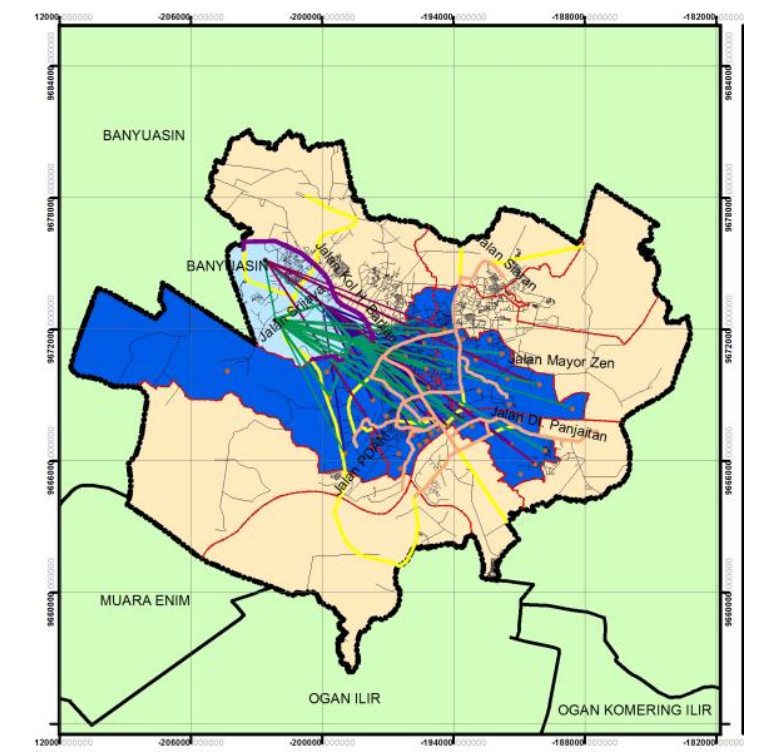

Gambar 1. Kecamatan Alang-Alang

Pada peta diatas, kawasan yang berwarna biru muda merupakan asal pergerakan yaitu Kecamatan Alang-Alang Lebar. Sedangkan untuk warna biru tua merupakan pusat Kota Palembang atau tujuan pergerakan yang dilalui oleh BRT atau angkutan umum lainya. Sehingga pada peta dapat dilihat, pergerakan paling besar terjadi dari pinggiran kota menuju pusat kota.

2) Moda Yang Digunakan

Pada penelitian ini, sampel yang dipilih merupakan masyarakat yang menggunakan kendaraan pribadi. Sehingga untuk karakteristik moda yang digunakan dibagi menjadi motor atau mobil. Berikut merupakan data moda yang paling banyak digunakan oleh pelaku pergerakan di Kecamatan Alang-Alang Lebar:

Tabel 5.

Moda Yang Digunakan Oleh Pelaku Pergerakan

\begin{tabular}{rlll}
\hline \multicolumn{1}{c}{ No. } & \multicolumn{1}{c}{$\begin{array}{c}\text { Moda Yang } \\
\text { Digunakan }\end{array}$} & Jumlah & Presentase \\
\hline 1. & Motor & 163 & 69 \\
2. & Mobil & 70 & 31 \\
Jumlah & & 233 & 100 \\
\hline \hline
\end{tabular}

Sumber: Hasil Survei, 2017

Setelah dilakukan identifikasi penggunaan moda kepada sampel masyarakat di Kecamatan Alang-Alang Lebar, terjadi pengurangan sampel pergerakan. Data pergerakan awal adalah 239 pergerakan, namun 7 pergerakan menggunakan kendaraan angkutan umum, sehingga sampel pergerakan tersebut dianggap tidak dapat dijadikan sampel sampai akhir penelitian. Dari 233 sampel pergerakan, sebesar 69\% merupakan pengguna motor. Sedangkan 31\% merupakan pengguna mobil. Mayoritas penggunaan motor dikarenakan oleh waktu tempuh yang lebih cepat menggunakan motor. Sehingga permintaan angkutan umum oleh masyarakat lebih kepada waktu pelayanan menuju tujuan pergerakan yang cepat. Data asal pergerakan awal yang semula adalah 239 menjadi 233 dikarenakan 7 pergerakan telah menggunakan kendaraan umum. 


\section{3) Maksud Pergerakan}

Dari data yang didapat oleh peneliti didapat maksud tujuan pergerakan masyarakat dari pinggiran Kota Palembang menuju pusat Kota Palembang didominasi oleh kegiatan bekerja yaitu sebesar 72,5\%. Berikut merupakan data maksud perjalanan masyarakat:

Tabel 6.

Data Variabel Maksud Pergerakan

\begin{tabular}{rlll}
\hline \multicolumn{1}{c}{ No. } & Maksud Pergerakan & $\begin{array}{c}\text { Jumlah } \\
\text { Pergerakan }\end{array}$ & $\begin{array}{c}\text { Presentase } \\
(\boldsymbol{\%})\end{array}$ \\
\hline 1. & Bekerja & 169 & 72.5 \\
2. & Sekolah/kuliah & 59 & 25.3 \\
3. & Belanja & 5 & 0.21 \\
Jumlah & & 233 & 100 \\
\hline \hline
\end{tabular}

Sumber: Hasil Survei, 2017

Dari data diatas, pergerakan yang terjadi dari Kecamatan Alang-Alang Lebar dibagi menjadi 3 yaitu berkerja, sekolah dan belanja. Sehingga dapat disimpulkan bahwa permintaan angkutan umum paling banyak terjadi ketika pagi hari saat ingin bekerja dan sore hari ketika pulang kerja.

4) Jarak Perjalanan

Jarak perjalanan pergerakan dilihat dari jarak sampel pergerakan dari asal menuju tujuan menggunakan kendaraan pribadi. Dari data yang didapat, jarak minimal pergerakan adalah $2 \mathrm{~km}$, sedangkan jarak perjalanan terpanjang adalah $15 \mathrm{~km}$. Jarak pergerakan sampel dikasifikasikan menjadi 4 klasifikasi untuk mengelompokan jarak pergeerakan sehingga dapat dilakukan proses analisis. Berikut merupakan data jarak pergerakan:

Tabel 7.

Data Variabel Jarak Perjalanan

\begin{tabular}{rlll}
\hline \hline No. & Jarak Pergerakan & $\begin{array}{c}\text { Jumlah } \\
\text { Pergerakan }\end{array}$ & $\begin{array}{c}\text { Presentase } \\
(\%)\end{array}$ \\
\hline 1. & $0-5$ & 45 & 19.4 \\
2. & $5.1-8$ & 124 & 53,3 \\
3. & $8.1-12$ & 63 & 27.1 \\
4. & $12.1-15$ & 1 & 0.2 \\
Jumlah & & 233 & 100 \\
\hline
\end{tabular}

Sumber: Hasil Survei, 2017

Dari data diaas, dapat diketahui jumlah masing-masing sampel pergerakan pada klasifikasi jarak pergerakan. Dimana jarak perjalanan terbanyak adalah pergerakan dengan jarak 5.1-8 km dari wilayah pinggiran menuju pusat kota.

5) Kesediaan Masyarakat Menggunakan BRT

Selanjutnya, pada penelitian ini akan dilihat sejauh mana ketersediaan masyarakat mau menggunakan kendaraan umum untuk mengurangi penggunaan kendaraan pribadi di Kecamatan Alang-Alang Lebar. Dari data didapat oleh peneliti, mayoritas pengguna kendaraan pribadi bersedia menggunakan kendaraan umum jika ketersediaan angkutan umum sesuai dengan permintaan masyarakat. Untuk lebih jelasnya, berikut merupakan data masyarakat yang bersedia menggunakan angkutan umum.
Tabel 8.

Kesediaan Menggunakan BRT

\begin{tabular}{|c|c|c|c|}
\hline No. & Masyarakat Yang Bersedia & Jumlah & $\begin{array}{c}\begin{array}{c}\text { Presentase } \\
(\%)\end{array} \\
\end{array}$ \\
\hline 1. & Ya & 199 & 85.4 \\
\hline 2 & Tidak & 34 & 14.6 \\
\hline Jumlah & & 233 & 100 \\
\hline
\end{tabular}

Sumber: Hasil Survei, 2017

Dari data diatas, dapat dilihat bahwa sebesar 85,4\% masyarakat bersedia menggunakan BRT. Akan tetapi masyarakat bersedia menggunakan kendaraan umum jika kendaraan umum tersebut mampu melayani kebutuhan masyarakat. Potensi tersebut dapat dijadikan sebagai masukan bagi pemerintah untuk melakukan pengembangan transportasi khususnya untuk pengembangan angkutan umum di wilayah pinggiran Kota Palembang Khususnya di Kecamatan Alang-Alang Lebar.

\section{B. Keterkaitan Karakteristik Pergerakan di Pinggiran dengan Kesediaan Menggunakan BRT}

Dalam menentukan keterkaitan antar variabel yang mempengaruhi kesediaan masyarakat menggunakan BRT menggunakan analisis Crosstab dilakukan 3 uji yaitu uji chi square, uji taraf signifikansi dan uji koefisiensi kontingensi. Berikut merupakan hasil dari analisis crosstab:

\section{1) Uji Chi Square}

Uji chi square dilakukan untuk mengetahui keterkaitan antar variabel dengan pengaruhnya terhadap kesediaan menggunakan BRT menggunakan nilai dari nilai pearson chi square. Adapun dasar pengambilan keputusan dalam dalam uji chi square adalah sebagai berikut:

- Nilai chi square hitung < nilai chi square tabel, maka Ho diterima

- Nilai chi square hitung > nilai chi square tabel, maka Ho ditolak

Berikut ini adalah nilai chi square yang dihasilkan berserta kesimpulannya setelah dilakukan analisis Crosstab antara karakteristik pelaku pergerakan dengan kesediaannya menggunakan BRT:

Tabel 9.

Hasil Dari Uji Chi Square

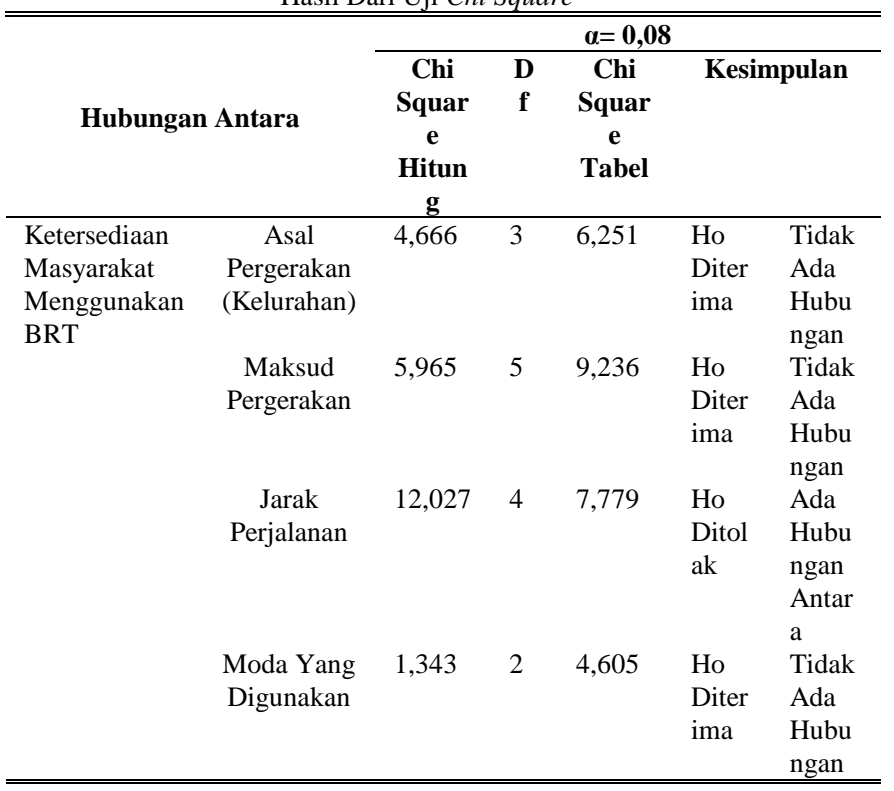


Berdasarkan nilai dari uji chi square diatas, diketahui bahwa variabel yang memiliki keterikatan adalah variabel lama perjalanan. Maka, jarak pergerakan mempengaruhi kesediaan masyarakat menggunakan BRT.

2) Uji Taraf signifikansi

Selain mengetahui dari nilai Pearson pada uji chi square, keterkaitan variabel juga dapat dilihat dari nilai taraf signifikansi. Dasar yang digunakan dalam mengambil keputusan pada nilai taraf signifikansi adalah sebagai berikut:

- Nilai Asymp. Sig $>\alpha(0,08)$, maka Ho diterima

- Nilai Asymp. Sig $<\alpha(0,08)$, maka Ho ditolak

Berikut merupakan hasil dari nilai taraf signifikansi terhadap keterkaitan variabel dengan kesediaan menggunakan BRT

Tabel 10.

Nilai Dari Uji Taraf Signifikansi

\begin{tabular}{lcccc}
\hline \multicolumn{1}{c}{ Variabel } & \multicolumn{4}{c}{$\boldsymbol{\alpha = 0 , 0 8}$} \\
\hline Ketersediaan & Asal & Maksud & Jarak & Moda \\
Masyarakat & Pergerakan & Pergerakan & Perjalanan & $\begin{array}{c}\text { Yang } \\
\text { Menggunakan }\end{array}$ \\
\cline { 2 - 5 } BRT & 0,198 & 0,310 & 0,017 & 0,511 \\
& Ho & Ho & Ho & Ho \\
& Diterima & Diterima & Ditolak & Diterima \\
\hline \hline
\end{tabular}

Setelah dilakukan uji taraf signifikansi, diketahui bahwa variabel yang mempengaruhi kesediaan masyarakat menggunakan BRT adalah jarak pergerakan. Dari hasil tersebut, diketahui bahwa hasil dari uji chi square dan nilai taraf signifikansi adalah sama.

3) Uji Koefisiensi Kontingensi

Uji koefisien kontingensi dilakukan untuk mengetahui keterkaitan antar variabel berdasarkan nilai koefisien kontingensi yang dihasilkan dalam analisis. Perbedaan dengan uji korelasi lainnya adalah uji koefisien kontingensi dapat digunakan untuk mengetahui sejauh mana keterkaitan antar variabel yang diuji dalam penelitian. Pedoman untuk memberikan interpretasi koefisien kontingensi adalah sebagai berikut [4]:

Tabel 11

Kriteria Interpretasi Uji Koefisien Kontingensi

\begin{tabular}{cc}
\hline \hline Nilai & Kriteria \\
\hline $0-0,199$ & Sangat Rendah \\
$0,2-0,399$ & Rendah \\
$0,4-0,599$ & Sedang \\
$0,6-0,799$ & Kuat \\
$0,8-1$ & Sangat Kuat \\
\hline
\end{tabular}

Sumber : Sugiyono, 2007

Dari tabel di atas diketahui bahwa koefisien kontingensi memiliki rentang nilai dari 0 hingga 1 . Apabila koefisien kontingensi semakin mendekati angka 1 maka hubungan kedua variabel semakin kuat. Sedangkan apabila koefisien kontingensi semakin mendekati angka 0 maka hubungan kedua variabel semakin rendah. Berikut merupakan nilai dari uji koefisiensi kontingensi dari variabel karakteristik pergerakan masyarakat dan keterkaitannya dengan kesediaan menggunakan BRT :
Tabel 12.

Nilai Uji Koefisiensi Kontingensi

\begin{tabular}{lcccc}
\hline \hline Variabel & $\begin{array}{c}\text { Asal } \\
\text { Pergeraka } \\
\text { n }\end{array}$ & $\begin{array}{c}\text { Maksud } \\
\text { Pergeraka } \\
\text { n }\end{array}$ & $\begin{array}{c}\text { Jarak } \\
\text { Perjalana } \\
\text { n }\end{array}$ & $\begin{array}{c}\text { Moda } \\
\text { Yang } \\
\text { Digunakan }\end{array}$ \\
\hline Ketersediaan & 0,138 & 0,156 & 0,219 & 0,075 \\
Masyarakat & Sangat & Sangat & Rendah & Sangat \\
Menggunaka & Rendah & Rendah & & Rendah \\
n BRT & & & & \\
\hline \hline
\end{tabular}

Dari hasil uji koefisiensi kontingensi diatas maka diketahui keterkaitan variabel asal pergerakan, maksud pergerakan dan moda yang digunakan sangat rendah. Sedangkan untuk variabel jarak pergerakan memiliki keterkaitan yang rendah.

\section{KESIMPULAN}

Dari penelitian yang telah dilakukan, dapat ditarik beberapa kesimpulan sebagai berikut:

1. Pergerakan yang terjadi di Kecamatan Alang-Alang Lebar paling banyak berasal dari Kelurahan Karya Baru dengan presentase sebesar $41,8 \%$. Sehingga permintaan angkutan umum paling besar berasal dari Kelurahan Karya Baru

2. Maksud pergerakan utama dari pelaku pergerakan adalah bekerja dengan presentase sebesar $72,5 \%$. Sehingga waktu perjalanan paling banyak yaitu pagi hari dan sore hari mengikuti jadwal pergi dan pulang bekerja pelaku pergerakan.

3. Moda yang paling banyak digunakan adalah kendaraan roda dua atau motor. Hal tersebut dikarenakan oleh waktu yang lebih cepat jika menggunakan motor menuju tujuan pergerakan.

4. Dari 233 pergerakan yang menggunakan kendaraan pribadi, sebesar 85,4\% atau sebesar 199 pergerakan bersedia menggunakan BRT jika terdapat jaringan feeder yang terintegrasi dengan BRT.

5. Kesediaan menggunakan BRT memiliki keterkaitan yang signifikan dengan vaiabel jarak perjalanan, dengan tingkat keterkaitan yang rendah. Sedangkan variabel asal pergerakan, tujuan pergerakan dan moda yang digunakan tidak memiliki keterkaitan yang signifikan. Sehingga dapat disimpulkan bahwa dalam menentukan kesediaan menggunakan BRT, masyarakat akan mempertimbangkan jarak pergerakan yang ditempuh dari wilayah pinggiran menuju pusat kota.

\section{DAFTAR PUSTAKA}

[1] S. A. Adisasmita, Transportasi dan Pengembangan Wilayah. Yogyakarta: Graha Ilmu, 2011.

[2] S. Joni Arliansyah, "Analisis Feeder system Menuju Halte II Transmusi Koridor VI Kota Palembang," 2013. [Online]. Available: download. portalgaruda.org/article.php?article $=89923 \&$ val $=4006$.

[3] R. Yudhaprawira, "Studi Pengadaan Park and Ride di Terminal Alang-Alang Lebar Kota Palembang," 2014. [Online]. Available: jurnal.unej.ac.id.

[4] Sugiyono, Statistika Untuk Penelitian. Jakarta: Alfabeta, 2015. 